Unnes Journal of Public Health

\title{
KEPATUHAN PENGGUNAAN SARUNG TANGAN DENGAN KECELAKAAN KERJA DI PERUSAHAAN DENGAN KECELAKAAN KERJA DI PERUSAHAAN PARQUET TEMANGGUNG
}

\author{
Yohanes Bahar Aprilliawan ${ }^{\bowtie}$, Evi Widowati \\ Jurusan Ilmu Kesehatan Masyarakat, Fakultas Ilmu Keolahragaan, Universitas Negeri \\ Semarang, Indonesia
}

\section{Info Artikel}

Sejarah Artikel:

Diterima 7 Maret 2016

Disetujui 13 Juni 2016

Dipublikasikan Juli 2016

Keywords:

Accident; The Using of

Gloves

\begin{abstract}
Abstrak
Kepatuhan penggunaan sarung tangan dapat mempengaruhi terjadinya kecelakaan kerja. Perilaku sesuai aturan dan konsisten dalam memakai sarung tangan yang wajib digunakan saat bekerja sesuai bahaya dan risiko kerja untuk menjaga keselamatan pekerja dan orang di sekelilingnya. Tujuan penelitian ini yaitu, untuk mengetahui Hubungan antara Kepatuhan Penggunaan Sarung Tangan Terhadap Kecelakaan Kerja pada Pekerja di PT. Tanjung Kreasi Parquet Industry Temanggung.

Jenis penelitian ini adalah penelitian analitik observasional dengan pendekatan cross sectional. Populasi berjumlah 207 pekerja dengan sampel sebanyak 66 pekerja (menggunakan teknik purposive sampling). Instrumen yang digunakan adalah angket. Analisis data dilakukan secara univariat dan bivariat (menggunakan uji chi square dengan $\alpha=0,05$ dengan alternatif yaitu uji fisher).

Hasil penelitian ini terdapat hubungan antara kepatuhan penggunaan sarung tangan dengan kecelakaan kerja pada pekerja PT. Tanjung Kreasi Parquet Industry yang menggunakan uji alternatif yaitu uji fisher dengan hasil $p$ value $0,018(<0,05)$ dengan OR (Odds Ratio), yaitu sebesar 6,14. Dari data tersebut responden yang tidak patuh menggunakan sarung tangan kain mempunyai kemungkinan 6,14 kali untuk mengalami kecelakaan kerja dibandingkan dengan responden yang patuh menggunakan sarung tangan kain. Saran yang diberikan kepada pekerja yaitu untuk selalu menggunakan sarung tangan kain saat jam kerja berlangsung.
\end{abstract}

\begin{abstract}
The obidience of using gloves could influence the working accident occurance. Obeying the rules and consistently using gloves are compulsory when working according to the working risks in order to keep the workers and the people arround safe. The aim of this research was to find out the correlation between the obidience of using gloves toward working accident of workers at PT. Tanjung Kreasi Parquet Industry Temanggung.

This research was observational analytic study using cross sectional design. The population was 207 workers and the sample was 66 workers (using purposive sampling technique). This research used questionnaire as the instrument to collect the data. The data analysis was done using univariat and bivariat (using chi square test, $\alpha=0,05$ and the alternative was fisher test).

The result showed that there was a correlation between the obidience of using gloves toward working accident of PT. Tanjung Kreasi Parquet Industry workers using alternative test that was fisher test with $p$ value $0,018(<0,05)$ and OR (Odds Ratio) was 6,14. According to the data, the disobey respondent that did not use gloves had 6.14 times possibility of working accident compared with those who using gloves. The suggestion for the workers was to always use gloves when working.
\end{abstract}

(C) 2016 Universitas Negeri Semarang

\footnotetext{
Alamat korespondensi:

Gedung F5 Lantai 2 FIK Unnes

Kampus Sekaran, Gunungpati, Semarang, 50229

E-mail: yohanesbahar.1dp6@gmail.com
}

ISSN 2252-6781 


\section{PENDAHULUAN}

Kecelakaan kerja merupakan kecelakaan yang terjadi berhubungan dengan kerja, demikian pula kecelakaan yang terjadi dalam perjalanan ke dan dari tempat kerja. Kecelakaan kerja merupakan kejadian tidak terduga dan tidak diinginkan, baik kecelakaan akibat langsung pekerja maupun kecelakaan yang terjadi pada saat pekerjaan sedang dilakukan (Handayani, 2012). Kecelakaan kerja sebagian besar disebabkan oleh human eror karena kesadaran dari pekerja akan keselamatan kerja masih kurang. Tidak patuhnya pekerja dalam memakai alat pelindung diri juga dapat mengakibatkan terjadinya suatu kecelakaan kerja (Respati, 2014).

\section{Menurut International Labour}

Organization (ILO) yaitu organisasi buruh interasional, setiap tahun terjadi sebanyak 337 juta kecelakaan kerja di berbagai negara yang mengakibatkan sekitar 3 juta orang pekerja kehilangan nyawa. Angka kecelakaan kerja di Indonesia termasuk dalam kategori yang tinggi. Menurut data dari jamsostek, angka kecelakaan kerja tahun 2010 mencapai 98.711. pada tahun 2011 lalu mencapai 99.491 kasus. Jumlah tersebut meningkat dibandingkan tahun sebelumnya. Pada tahun 2012 angka kecelakaan kerja mencapai 103.000 kasus. Tahun 2013 kecelakaan kerja meningkat mencapai 103.285 kasus (Supriyanto, 2015).

Menurut data PT. Jamsostek tahun 2010 kejadian kecelakaan kerja di Jawa Tengah sebanyak 86.693 kasus, tahun 2011 kejadian kecelakaan kerja sebanyak 99.491 kasus. Menurut data kecelakaan kerja Disnakertrans pada tahun 2012 tercatat di provinsi Jawa Tengah terjadi kasus kecelakaan kerja sebanyak 14.280 kasus kecelakaan kerja, kemudian pada tahun
2013 sampai triwulan 4 telah terjadi kecelakaan kerja sebanyak 4.601 kasus (Respati, 2014).

Kecelakaan kerja akibat tidak menggunakan APD di Indonesia masih cukup tinggi, yaitu: $60 \%$ tenaga kerja cedera kepala karena tidak menggunakan topi pengaman, 90\% tenaga kerja cedera wajah karena tidak menggunakan alat pelindung wajah, $77 \%$ tenaga kerja cedera kaki karena tidak menggunakan sepatu pengaman, dan $66 \%$ tenaga kerja cedera tangan karena tidak menggunakan alat pelindung tangan.

Pada tahun 2010 kejadian kecelakaan kerja pada perusahaan kayu sebanyak 54.398 kasus, tahun 2011 sebanyak 48.511 kasus. Pada tahun 2012 kecelakaan kerja sebanyak Tahun 2012 sebanyak 53.319 kasus dan Tahun 2013 sebanyak 50.089 kasus (Titilia, 2013).

Pada proses produksi dibagi menjadi 3 tahapan yaitu sawmill, middle layer, preparation dan parquet yang pertama yaitu sawmill. Pada proses ini adalah tahap pemotongan kayu menjadi potongan papan yang kemudian di sortir sesuai grade. Potensi bahaya pada proses sawmill adalah terkena mesin potong pada tangan dan tertimpa kayu log. Proses kedua yaitu middle layer, pada proses ini dimulai dengan penghalusan permukaan kayu yang kemudian dibelah dan disusun untuk direkatkan dengan veneer. selanjutnya diproses pada mesin Cold Press untuk direkatkan kembali dan dikeringkan pada mesin Hot Press, kemudian material tersebut dipotong sesuai ukuran dengan menggunakan mesin Multi Rip. Potensi bahaya pada proses middle layer adalah tangan terkena mesin potong Multi Rip, dan mesin Hot Press. Proses terakhir yaitu pada bagian preparation dan parquet, pada tahapan 
ini Lumber lamella disizing sesuai ukuran melalui tahapan dengan pembelahan dengan mesin $X$-cut, pemotongan dengan

mesin Riping kemudian dilakukan penghalusan permukaan dengan mesin sander. Selanjutnya dilakukan pegabungan antara Top layer dengan Midlle layer pada mesin Hot Prees dengan bantuan lem, dan dilakukan perataan material untuk memeproleh lantai kayu yang halus.

Dari uraian diatas potensi bahaya yang tertinggi adalah sub departement preparation. Pada proses preparation potensi bahaya yang ditimbulkan berupa tangan tergores kayu, terkena serpihan kayu pada tangan, terjepit kayu. Untuk menekan potensi bahaya tersebut menjadi kecelakaan kerja, sub department preparation PT. TKPI menyediakan sarung tangan kain. Dari beberapa kecelakaan kerja yang terjadi pada sub department preparation terjadi karena goresan kayu pada tangan. Pada tahun 2014 terjadi 12 kecelakaan dari 207 karyawan, 6 di antaranya adalah luka robek pada tangan karena tidak menggunakan sarung tangan yang sudah di sediakan oleh perusahaan.

PT. Tanjung Kreasi Parquet Industry (TKPI) adalah perusahaan yang bergerak dibidang pengolahan kayu. Kecelakaan terbagi dalam kategori kecelakaan ringan yaitu luka ringan atau sakit ringan. Kategori kecelakaan sedang yaitu luka berat atau parah dan sirawat di rumah sakit dan kategori kecelakaan berat yaitu cidera parah, cacat seumur hidup, tidak mampu bekerja (Sompie, 2012). Pada PT. TKPI yang di kategorikan kecelakaan ringan adalah kecelakaan terkena serpihan kayu, luka lecet pada tangan dan masih bisa berikan penanganan oleh poliklinik PT. TKPI. Kategori kecelakaan sedang adalah luka robek yang membutukan jahitan dan membutuhkan waktu penyembuhan sekitar satu minggu. Untuk kecelakaan kategori berat adalah kecelakaan yang menimbulkan cidera parah seperti patah tulang, dan mengakibatkan kehilangan hari kerja.

Pada tahun 2014 terjadi 31 (2,39\%) kecelakaan kerja dari 1295 karyawan. Kategori kecelakaan ringan sebanyak 10 $(32,25 \%)$ kecelakaan kerja, kategori sedang sebanyak 17 (54,83 \%) kecelakaan kerja, dan kategori berat sebanyak 4 kecelakaan kerja. Pada bulan Januari sampai bulan Maret 2015 terjadi 12 kecelakaan. Pada bulan Januari terjadi 2 (17\%) kecelakaan kerja dalam kategori sedang, dan pada bulan Februari 2015 terjadi 6 (50\%) kecelakaan kerja, 1 (17\%) kecelakaan kerja ringan, dan 5 (83\%) kecelakaan kerja sedang. Bulan Maret terjadi 4 (33\%) kecelakaan kerja dengan kategori ringan. Upaya yang dilakukan untuk menekan kejadian kecelakaan kerja PT. TKPI menyediakan alat pelindung diri sebagai tindakan proteksi dini terhadap bahaya kecelakaan kerja yang timbul di tempat kerja. Alat pelindung diri yang disediakan terdiri atas masker, sarung tangan kain, sarung tangan karet, sarung tangan kulit, dan ear plug. Untuk masker, dan sarung tangan kain semua pekerja wajib untuk memakai. Pada bagian produksi APD ditambah dengan ear plug khususnya pada pekerjaan diarea mesin planner, karena dibagian ini kebisingan melebihi NAB (94,6 dBA). Sarung tangan karet digunakan pada bagian pengeleman, dan sarung tangan kulit digunakan pada bagian boiler.

Berdasarkan data dari PT. TKPI Temanggung Tahun 2014 telah memberikan APD berupa Ear Plug, masker kain, sarung tangan kain, sarung tangan karet, dan sarung tangan kulit. Pada bulan Januari telah dibagikan APD sebanyak 1723 buah, dan bulan Februari mengalami penurunan menjadi 845 buah. Pembagian 
APD bulan Maret sebanyak 1646 buah, bulan April sebanyak 1931 buah, bulan Mei meningkat menjadi 2233 buah. Bulan Juni telah dibagikan APD sebanyak 1723, bulan Juli sebanyak 1637 buah. Pembagian APD pada bulan Agustus sebanyak 2105 buah, bulan September sebanyak 2510 buah, dan bulan Oktober sebanyak 2001 buah. Bulan November telah dibagikan APD sebanyak 2232 buah, dan mengalami penurunan pada bulan Desember menjadi 1871 buah. Data pembagian APD PT. TKPI Temanggung tahun 2015. Pada bulan Januari telah dibagikan APD sebanyak 1980 buah, bulan Februari sebanyak 1744, bulan Maret sebanyak 1862 buah, dan bulan April sebanyak 1613 buah.

Berdasarkan uraian tersebut, peneliti termotivasi untuk mengetahui hubungan antara kepatuan penggunaan sarung tangan dengan kejadian kecelakaan kerja. Sehingga judul dalam penelitian ini adalah Hubungan antara Kepatuhan Penggunaan Sarung Tangan dengan Kejadian Kecelakaan Kerja pada Pekerja di PT.

Tanjung Kreasi Parquet Industry Temanggung.

\section{METODE}

Penelitian ini menggunakan metode penelitian analitik observasional dengan pendekatan cross sectional yang menjelaskan hubungan antara variabel bebas (kepatuhan penggunaan sarung tnagan) dan variabel terikat (kecelakaan kerja) melalui pengujian hipotesis.

Alur pengambilan sampel

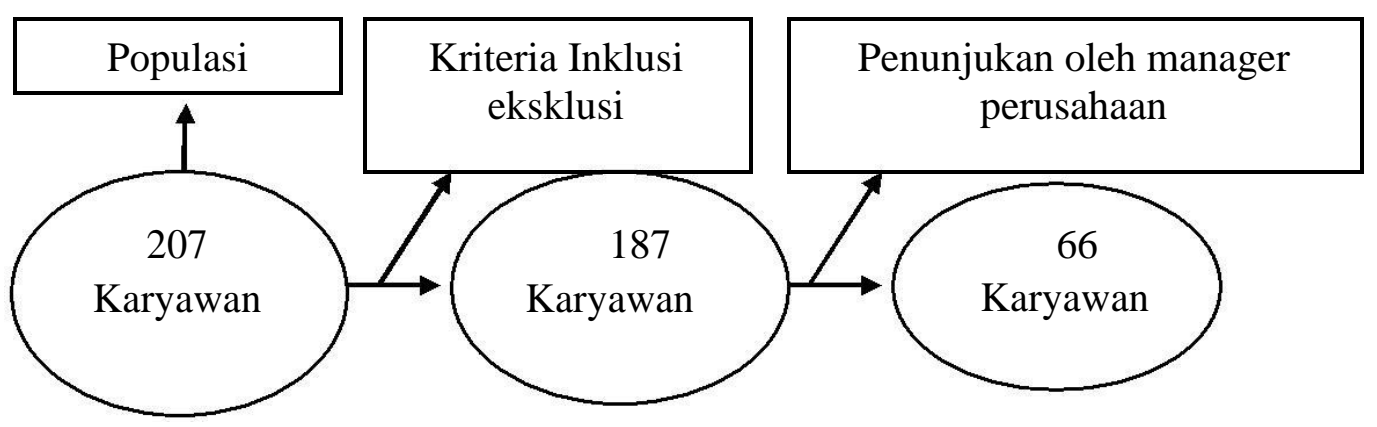

Cara pemilihan sampel yaitu dari 207 karyawan Sub Departement Preparation dipilih karyawan dengan kriteria inklusi dan eksklisi yang sudah ditentukan dan terdapat 187 karyawan yang memenuhi kriteria. Kemudian dari 187 karyawan terpilih 66 karyawan dengan penunjukan oleh pihak perusahaan melalui kepala bagian Sub Departement Preparation yang dapat menjadi responden dalam penelitian ini (Notoatmodjo, 2010).

Adapun kriteria inklusi adalah sebagai berikut:

1. Karyawan dengan tingkat pendidikan SMP dan SMA.
2. Karyawan dengan usai 20 tahun sampai 45 tahun.

Kritetia eksklusi pengambilan sampel:

1. Tidak bersedia menjadi responden.

2. Bukan karyawan bagian Sub Departement Preparation.

Analisis yang digunakan dalam penelitian ini yaitu menggunakan analisis univariat dan analisis bivariat. Uji statistik dalam penelitian ini adalah uji chi square, dengan uji alternatif Fisher's karena jenis hipotesisnya adalah hipotesis asosiasi yang akan menjawab apakah terdapat hubungan 
antara dua variabel dengan skala pengukuran variabel kategorik dan data HASIL DAN PEMBAHASAN tidak berpasangan.

Tabel 1: Karakteristik Responden Berdasarkan Tingkat Pendidikan

\begin{tabular}{llll}
\hline No & Tingkat Pendidikan & Frekuensi & Prosentase (\%) \\
\hline 1. & SMP & 21 & 31,8 \\
2. & SMA & 45 & 68,2 \\
\hline Total & 66 & 100 \\
\hline
\end{tabular}

Tabel 2: Karakteristik Responden Berdasarkan Usia

\begin{tabular}{llll}
\hline No & Usia & Frekuensi & Prosentase (\%) \\
\hline 1. & 20 tahun -24 tahun & 4 & 6,1 \\
2. & 25 tahun -29 tahun & 5 & 7,6 \\
3. & 30 tahun -34 tahun & 20 & 30,3 \\
4. & 35 tahun -39 tahun & 23 & 34,8 \\
5. & 40 tahun -45 tahun & 14 & 21,2 \\
\hline \multicolumn{2}{l}{ Total } & 66 & 100 \\
\hline
\end{tabular}

Tabel 3: Distribusi Kepatuhan Penggunaan Sarung Tangan

\begin{tabular}{llll}
\hline No & Kategori & Frekuensi & Prosentase (\%) \\
\hline 1. & Patuh & 20 & 30,3 \\
2. & Tidak Patuh & 46 & 69,7 \\
\hline Total & 66 & 100 \\
\hline
\end{tabular}

Tabel 4: Distribusi Kecelakaan Kerja

\begin{tabular}{llll}
\hline No & Kategori & Frekuensi & Prosentase (\%) \\
\hline 1. & Kecelakaan Kerja & 57 & 86,4 \\
2. & Tidak Kecelakaan Kerja & 9 & 13,6 \\
\hline Total & 66 & 100 \\
\hline
\end{tabular}

Tabel 5: Tabulasi Silang Penggunaan Sarungan Tangan dengan Kecelakaan Kerja

\begin{tabular}{|c|c|c|c|c|c|c|}
\hline \multirow[t]{3}{*}{ Penggunaan sarung tangan } & \multicolumn{4}{|c|}{ Kecelakaan Kerja } & \multirow{3}{*}{$A$} & \multirow{3}{*}{$\rho$} \\
\hline & \multicolumn{2}{|c|}{$\begin{array}{l}\text { Kecelakaan } \\
\text { Kerja }\end{array}$} & \multicolumn{2}{|c|}{$\begin{array}{l}\text { Tidak Kecelakaan } \\
\text { Kerja }\end{array}$} & & \\
\hline & Jumlah & Prosentase & Jumlah & Prosentase & & \\
\hline Tidak Patuh & 43 & $93,5 \%$ & 3 & $6,5 \%$ & 005 & 0018 \\
\hline Patuh & 14 & $70 \%$ & 6 & $30 \%$ & $0,0 J$ & 0,010 \\
\hline Total & 57 & & 9 & & & \\
\hline
\end{tabular}

Hasil analisis menggunakan uji sel. Diperoleh nilai $\mathrm{p}$ value $0,018(<0,05)$ alternatif yaitu Fisher's karena pada tabel sehingga Ho ditolak. Hal ini menunjukkan silang 2x2 dijumpai nilai harapan (Expacted bahwa ada hubungan antara kepatuhan Count) kurang dari 5 , lebih dari $20 \%$ jumlah penggunaan sarung tangan terhadap 
kejadian kecelakaan kerja di PT. Tanjung Kreasi Parquet Industry Temanggug. Parameter kekuatan hubungan yang dipakai adalah OR (Odds Ratio), yaitu sebesar 6,14. Dari data tersebut responden yang tidak patuh menggunakan sarung tangan kain mempunyai kemungkinan 6,14 kali untuk mengalami kecelakaan kerja dibandingkan dengan responden yang patuh menggunakan sarung tangan kain.

Kecelakan yang terjadi pada pekerja yang tidak patuh menggunakan sarung tangan kain pada hari kerja dan saat jam kerja berlangsung berupa tangan tergores kayu, terkena serpihan kayu. APD (Sarung Tangan Kain) merupakan suatu alat yang diperlukan untuk melindungi pekerja dari potensi bahaya fisik yang tidak dapat dihilangkan melalui pengendalian teknik maupun pengendalian administratif (Sugarda, 2014). APD (Sarung Tangan Kain) bukanlah alat yang nyaman apabila dikenakan tetapi fungsi dari alat ini sangatlah besar karena dapat mencegah kecelakaan kerja pada waktu bekerja. Berdasarkan pasal 14 huruf c UU No. 1 Tahun 1970 tentang keselamatan kerja, perusahaan wajid menyediakan APD (Sarung Tangan Kain) secara cuma-cuma terhadap tenaga kerja dan orang lain yang memasuki tempat kerja. APD harus bisa memberikan perlindungan dari potensi bahaya ditempat kerja, nyaman dipakai, dan tidak mengganggu pekerjaan (Solichin, 2014). Apabila kewajiban tersebut tidak dipenuhi merupakan suatu pelanggaran undang-undang. Berdasrkan Pasal 12 huruf b, tenaga kerja diwajibkan memakai APD (Sarung Tangan Kain) yang telah disediakan. Dalam menyediankan APD (Sarung Tangan Kain) prioritas pertama perusahaan adalah melindungi pekerjanya secara keseluruhan. Katersediaan APD (Sarung Tangan Kain) harus sesuai dengan bahaya yang ada diperusahaan, terbuat dari material yang tahan terhadap bahaya tersebut, nyaman dipakai.

Dari ketentuan undang-undang diatas masih ditemukan kejadian kecelakaan kerja yang disebabkan oleh beberapa faktor yaitu penggunaan alat pengaman yang tidak sesuai, sikap dan cara kerja yang kurang baik, penggunaan peralatan yang tidak aman, kesadaran tentang keselamatan

kurang, tidak adanya sosialisasi keselamatan kerja, dan sikap kerja yang kurang baik (Muliatna, 2014)

Sarung tangan berfungsi meilindungi tangan dari benda yang berbahaya yang dapat melukai tangan. Sarung tangan juga sangat membantu pada pekerjaan yang dapat melukai tangan. Sarung tangan juga sangat membantu pada pekerjan yang berkaitan dengan benda kerja yang panas, tajam ataupun lancip (Sugarda, 2014). Sarung tangan yang digunakan untuk melindungi tangan dari kecelakaan kerja terdiri dari beberapa jenis yaitu sarung tangan metal mesh, sarung tangan vinyl dan neoprene, sarung tangan karet, sarung tangan padded cloth, sarung tangan heat resistant, sarung tangan latex disposable, sarung tangan kain (Buntarto, 2015:47).

Sarung tangan metal mesh melindungi tangan dari benda tajam dan mencegah terpotong akibat benda tajam. Sarung tangan vinyl dan neoprene berfungsi melindungi tangan dari bahan kimia beracun. Sarung tangan karet berfungsi melindungi saat bekerja disekitar arus listrik. Sarung tangan padded cloth melindung tangan dari ujung yang tajam, pecahan gelas, kotoran dan vibrasi. Sarung tangan heat resistant berfungsi untuk melindungi tangan dari panas. Sarung tangan kain berfungsi melindungi tangan dari goresan benda dengan permukaan kasar. 
Pada proses preparation terdapat beberapa tahapan. Tahap pertama yaitu Lumber lamella disizing sesuai ukuran melalui tahapan dengan pembelahan dengan mesin $X$-cut, pada tahap ini jenis sarung tangan yang seharusnya digunakan adalah metal mesh yang berfungsi melindungi tangan dari benda tajam dan mencegah terpotong akibat benda tajam, namun belum disedikan oleh perusahaan. Tahap kedua yaitu pemotongan dengan mesin Riping, pada tahap ini sarung tangan yang seharusnya digunakan adalah metal mesh, namun belum disediakan oleh perusahaan. Tahap selanjutnya dilakukan penghalusan permukaan dengan mesin sander, pada tahap ini sarung tangan yang seharusnya digunakan adalah sarung tangan kain berfungsi melindungi tangan dari goresan benda dengan permukaan kasar, untuk sarungan tangan kain sudah disediakan oleh perusahaan. Tahap terakhir pada Sub Departement Preparation adalah melakukan pegabungan antara Top layer dengan Midlle layer pada mesin Hot Prees dengan bantuan lem, dan dilakukan perataan material untuk memperoleh lantai kayu yang halus. Pada tahap ini sarung tagan yang seharusnya digunakan adalah sarung tangan heat resistant berfungsi untuk melindungi tangan dari panas namun belum disediakan oleh perusahaan.

Dari beberapa tahapan pada departement preparation, kecelakaan kerja sering terjadi pada tahap penghalusan permukaan dengan mesin sander. Angka kecelakaan kerja pada tahun 2014 terjadi 12 kecelakaan dari 207 karyawan, 6 di antaranya adalah luka robek pada tangan karena tidak menggunakan sarung tangan. Karyawan yang tidak menggunakan sarung tangan kain ketika sedang bekerja yang mengakibatkan terjadinya kecelakaan kerja berupa tangan tergores kayu, dan terkena serpihan kayu. Dengan dilakukannya penelitian ini diharapkan pekerja dapat patuh menggunakan sarung tangan kain yang sudah disediakan oleh perusahaan sehingga angka kecelakaan kerja akibat tidak menggunkakna sarung tangan kain saat bekerja dapat berkurang.

Penelitian sebelumnya yang dilakukan Egriana Handayani (2012) pada bagian rustic di PT. Borneo Melintang Buanan diketahui bahwa ada hubungan antara kepatuhan penggunaan sarung tangan dengan kecelakaan kerja dengan $p$ value $0,009(<0,05)$. Perilaku sesuai aturan dan selalu memakai sarung tangan kain pada hari kerja dan saat jam kerja berlangsung sesuai bahaya dan risiko kerja untuk menjaga keselamatan pekerja (Supriyanto, 2014). Pekerja diwajibkan untuk selalu memakai sarung tangan kain sebagai pelindung dari saat bekerja yang sudah disediakan oleh perusahaan.

\section{SIMPULAN}

Berdasarkan hasil uji statistik yang telah dilakukan, maka dapat disimpulkan bahwa ada hubungan antara kepatuhan penggunaan sarung tangan kain dengan kecelakaan kerja pada pekerja sub departemen preparation di PT. TKPI Temanggung. Hal ini berdasarkan uji alternatif yaitu uji fisher denagn hasil $p$ value 0,018 $(<0,05)$ dengan OR (Odds Ratio), yaitu sebesar 6,14. Dari data tersebut responden yang tidak patuh menggunakan

sarung tangan kain mempunyai kemungkinan 6,14 kali untuk mengalami kecelakaan kerja dibandingkan dengan responden yang patuh menggunakan sarung tangan kain.

\section{UCAPAN TERIMA KASIH}


Terimakasih kami sampaikan kepada Dekan Fakultas Ilmu Keolahragaan Universitas Negeri Semarang, Ketua Jurusan Ilmu Kesehatan Masyarakat, Bapak Ibu dosen Jurusan Ilmu Kesehatan Masyarakat, PT. Tanjung Kreasi Parquet Industry atas ijin dan bantuan yang diberikan dalam pelaksanaan penelitian ini. Serta semua pihak yang tidak dapat disebutkan satu persatu yang telah membantu dan mendukung dalam proses pelaksanaan penelitian ini.

\section{DAFTAR PUSTAKA}

Sugarda, Asri, 2014, Analisis Pengetahuan Penggunaan Alat Pelindung Diri Terhadap Allowance Proses Kerja Pemotong Kayu PT. PAL Indonesia, Volume 9, No 3, September 2014

Sompie, Bonny F, 2012, Pengaruh Kesehatan, Pelatihan dan Penggunaan Alat Pelindung Diri Terhadap Kecelakaan Kerja Pada Pekerja Konstruksi di Kota Tomohon, Volume 2, No 4, Novemver 2012.

Buntarto, 2015, Panduan Praktis Keselamatan dan Kesehatan Kerja untuk Industri, Yogyakarta: Pustaka Baru Press.
Muliatna, I Made, 2014, Pengaruh Alat Pelindung Diri Terhadap Keselamatan dan Kesehatan Kerja Karyawan dibengkel M.Mischan Kalijudan Surabaya, Volume 3, No 3, Tahun 2014.

Handayani, Egriana, 2012, Hubungan antara Penggunaan Alat Pelindung Diri, Umur, dan Masa Kerja dengan Kecelakaan Kerja pada Pekerja Bagian Rustic di PT. Borneo Melintang Buana Eksport Yogyakarta, Volume 4, No 3, September 2012.

Titilia, Maria, 2014, Hubungan Tingkat Pengetahuan dan Pendidikan Pekerja terhadap Penggunaan Alat Pelindung Diri, Volume 4, No 1, Mei 2014.

Respati, Rida 2014, Analisis Keselamatan dan Kesehatan Kerja pada Paket Pekerja Pembangunan Jalan Lingkar Luar Kota Palangkaraya, Volume 3, No 1, Desember 2014.

Supriyanto, Riyanto, 2015, Kepatuhan Pemakaian Alat Pelindung Diri pada Pekerja Las di Indramayu, Volume 1, No 3, Desember 2015.

Notoatmodjo, Soekidjo, 2010, Metodologi Penelitian Kesehatan, Jakarta: Reneka Cipta.

Solichin, 2014, Penerapan Personal Protective equitment (Alat Pelindung Diri) pada Laboraturium Pengelasan, Volume 1, No 1, April 2014. 
